\title{
Holding the Future Together: towards a theorisation of the spaces and times of transition
}

Gavin Brown, Peter Kraftl, Jenny Pickerill and Caroline Upton

Department of Geography

University of Leicester

University Road,

Leicester LE1 7RH

Email: gpb10@le.ac.uk 


\title{
Holding the Future Together: towards a theorisation of the diverse spaces and times of transition
}

\begin{abstract}
Social scientists often use the notion of 'transition' to denote diverse trajectories of change in different types of bodies: from individuals, to communities, to nation-states. Yet little work has theorised how transition might occur across, between or beyond these bodies. The aim of this paper is to sketch out a multiple, synthetic and generative (but by no means universal) theory of transition. Primarily drawing on the British context, we explore and exemplify two contentions. Firstly, that the notion of transition is being increasingly deployed to frame and combine discourses in terms of community development, responses to environmental change and the individual lifecourse. Specifically framed as transition, such discourses are gaining increasing purchase in imagining futures that reconfigure, but do not transform, assumed neoliberal futures. Our second contention is that these discourses and policies must try to 'hold the future together' in one or more senses. They must wrestle with a tension between imminent threats (climate change, economic non-productivity) which weigh heavily on the present and its possible futures, and the precarious act of redirecting those futures in ways that might better hold together diverse social groups, communities and places.
\end{abstract}

Key words: Transition and transformation; Transition Towns; commons; policy transitions

\section{Introduction}

The past few years have witnessed gathering interest in processes, practices and philosophies of transition and in their relations to possible futures. The term 'transition' implies a pressing sense of temporality; of progress, change and, in many cases, the irreversible passage of time as a person, group or thing (or combination thereof) develops from one state of being to another. Such a simple 
definition belies the complexity of a term that entails, in different times and places, both passivity and programmatic intentionality. To cite Hendriks $(2009,346)$, 'transition' may thus function as a 'boundary object, enabling actors ....to attach their own meanings and aspirations to the concept'. Transition may be done by an agent or group of actors as much as it may be done to an agent or group. Moreover, the implication of transition with change - whether social, political, technical, whatever - is a problematic one, as are teleological notions of transition goals and futures. Furthermore, attempts to delineate 'transition' as a distinct form of change, in contrast to, say transformation, revolution, development, disjuncture or merely the run-of-the-mill happenings that constitute the vitality of everyday life, remain under-theorised (Smith and Stenning, 2006; Seigworth, 2000; Gardiner, 2004). Generally, we posit an (albeit hazy and contested) division between transformation and transition. We contend that transformation, especially in the context of writings on post Soviet spaces, is typically understood as a process - or break, specifically in the shift from centralised state socialist planning to capitalist market economies after 1989 . Thus, the concept of transformation is typically used to describe societies and spaces that have experienced an ostensibly wholesale shift in the economic mode of production (accompanied by reordering of political institutions and the restructuring of social landscapes). These arguments are developed further in subsequent sections.

In contrast, transition is more widely used to denote iterative, incremental processes of change, towards uncertain futures. Transition and transformation are (arguably) distinguished not only by the depth, process and nature of change, but by their relations to the past, present and particularly the future. As we will demonstrate, transition discourses resonate with recent attention to the geographical framing of futurity in governmental planning regimes. As Evans (2010: 22) notes, future threats (like climate change and obesity) are "made real in the present" through attention to and projections of the condition of future social spaces should current trends continue. Such planning techniques seek to predict and ultimately determine futures, foreclosing the possibility that the future might be realised differently than models and projections might allow. Ben Anderson's recent 
work (e.g. Anderson, 2010) maps out multiple modalities and projections through which the future might be anticipated, and through which determinate and indeterminate threats managed. His three-fold schema - of pre-emption, precaution and preparedness - offers a striking theorisation of how modes of future-thinking are deployed to compel action in the present. As he puts it (Anderson, 2010: 2), "forms of anticipatory action [offer] a seemingly paradoxical process whereby a future becomes cause and justification for some form of action in the here and now". Hence, futures may be assembled through styles (statements about the future), practices (the performance, imagination or calculation of the future, perhaps through predictors of human behaviour) and logics (programmes and policies that formalise action in the present, for the sake of the future) (Anderson, 2010: 2-3). Our claim in this paper is that the deployment of the term 'transition' in policy discourses, everyday lives and social-scientific research is becoming increasingly varied but, as it does so, is becoming increasingly central to the spaces and times of future-thinking, such as those styles, practices and logics briefly listed above. Similarly, we claim that the term is being used increasingly to combine different forms of transition - lifecourse, environmental, political-economic - in some sense holding these diverse forms of transition together in order, in some sense, to hold the future together.

A further complication is that the term transition has significant political connotations and functions in terms of how the future is related and related-to. For, the term has been deployed by organisations who do not seek to sanction neoliberal political, economic and social orderings, but, similarly, do not necessarily seek to transform or replace them either. As we indicate later in this paper, many members of the contemporary Transition Town movement in the UK are resistant towards and seek alternatives to neoliberal capitalism. Yet - in articulating 'realistic', applicable and socially-acceptable approaches to dealing with the threat of climate change - the movement has been the target of critics for whom transition is merely 'coping' or tinkering where more radical forms of change are required (TRAPESE, 2008). Links between 'transitions' and resilience or adaptive management debates are pertinent here. Foxon et al .(2009a) highlight inbuilt 
conservatism in both concepts, but especially the latter, with its focus on iterative learning processes and experimentation to facilitate maintenance and enhance resilience of critical system functions. In contrast they suggest that transitions management takes a more directive, goal-oriented stance to the future and opens up greater possibilities for regime change, albeit specifically within the context of debates around socio-technical transitions. A broader understanding of transitions, as deployed by the Transition Town movement, comes closer to concepts of resilience, wherein ongoing, iterative changes within aspects of the system facilitate its adaptive capacity and ability to withstand external shocks.

Thus, in recent debates around transition, a key point of contestation has fomented around the question of what, specifically, diverse forms of transition might do (or not do) to neoliberal modes of social ordering and governance. Of equal importance, but somewhat less prominent in contemporary debates, are questions of individual and collective relations to the future implicit in particular modes of transition. Thus, despite gathering social-scientific interests in all kinds of transition - lifecourse, postsocialist, environmental, socio-technical (some of which are briefly reviewed later in the paper) - it is our contention that this question of the future, specifically in and of transitions, has remained implicit at best. Moreover, we question the extent to which such diverse (which may exhibit tensions with one another) are being held together in forms of transition that try to anticipate and prepare for uncertain environmental futures.

A similar critique can be aimed at environmental scenario building techniques, developed in the wake of the Millennium Ecosystem Assessment. Such techniques are increasingly being deployed in attempts to develop informed responses to contemporary crises. Although they have been criticised for their weak engagement with social contexts and processes (e.g. Garb et al., 2008), they do at least map a range of possible futures. However, as we alluded above, that which delineates transition from other forms of change is, in part, unclear because the future, in and of such techniques, and the place of individual, lifecourse transitions within such techniques, remains undertheorised. A series of questions flows from this assertion. What do transition practices seek to do, in 
the future? What kinds of futures do transition organisations imagine or seek to avoid? How could progress towards (and life within) those futures be controlled, regulated and governed, and by whom? How are diverse forms, spaces and times of transition held together in order to hold together such controlled, regulated and/or governed futures? And perhaps most critical of all - in terms of this special issue - in which places, at what scales and through which kinds of socio-spatial ordering might transition practices take hold of the future?

In the context of the enormity of these questions - and the many contemporary social practices, politics and philosophies calling themselves 'transition' - this paper attempts, rather more modestly, to provide a theorisation of aspects of transition thinking in respect of possible environmental futures. The paper is illustrated by two case studies of ways in which limited (but prominent) forms of broadly environment-focused transition, based in the United Kingdom, attempt to figure the future. We argue that each of these forms of transition attempts, somehow, to hold the future together. Echoing the observations made above, they attempt to hold together (more-or-less) the contemporary neoliberal status quo, whilst seeking (more-or-less) to hold together diverse social groups in preparedness for particular social or environmental threats, whilst seeking (more-or-less) to anticipate how communities - of various scales - might hold together and become more resilient in the face of such threats.. Our paper proceeds as follows. In order to frame our later analyses, we begin by briefly returning to and developing two conceptualisations of transition that have been received considerable attention in recent geographical scholarship at two distinct, but overlapping spatial scales: first, we articulate the proposed distinction between transition and transformation; second, we summarise and critique recent work on lifecourse transitions. Subsequently, we analyse two prominent, UK-based deployments of the term transition: recent UK Government policy on Low Carbon Transitions; and the Transition Towns movement.

Two starting points: State 'transition/transformation' and individual lifecourse transitions 
'Transition' has been widely posited as a marker and process characterising the countries of the former Soviet Union. However, this region and its recent history forms a historical-geographical context in which some geographers have explicitly contested the suggestion that the process of social change that unfolded was a 'transition' and was, rather, a form of 'transformation' (Lynn 1999; Smith 1996; Pickles and Smith 1998). Here we explicitly address the debates about transitions versus transformations in political-economic terms alongside a consideration of how these contrasting processes relate to the future. We do so because we believe geographies of the future (especially when they regard socio-technological and socio-political responses to anticipated environmental challenges) need to intersect with broader political-economic debates about the nature of the future that is being envisioned. In contesting the identification of these processes of change as transition, geographers such as Lynn and Smith have sought to move beyond debates elsewhere in the social sciences that attempted to analyse different 'modes of transition', conceptualised quite narrowly as the means by which particular polities experienced regime change to different forms of democracy (Karl and Schmitter 1991). In many post-socialist countries, some degree of democratization occurred more or less simultaneously with neoliberal marketisation of economic relations and the privatisation of some forms of property. At the time, international neoliberal strategists from the World Bank and International Monetary Fund promoted the importance of a rapid transformation implemented through 'shock therapy' to limit the opportunities for resistance and to ensure that there could be no return to Soviet-style centralised planning (Lynn 1999: 834).

\footnotetext{
"Each [technique of transformation sought] to de-monopolise the power of the state and separate the state from the economy and civil society. Marketisation [sought] to free-up the economy. Privatisation [sought] to break up economic monopolies in the spheres of production, purchasing and distribution. Democratisation [and de-communisation [aimed] to break the hold of the
} 
Communist Party in political life and to enable a rejuvenated civil society to emerge. ... Each technique of transformation, along with its specific instruments and policies, [sought to bring] about a fundamental reorientation in the position of post-communist states in the global economy." (Smith and Pickles 1998: 2 -4; our emphasis).

The 'shock therapy' enacted in the post-socialist transformations of the 1990s contrasts with the attempts to build local resilience to the impact of anticipated future shocks as advocated in relation to sustainability transitions by the Transition Towns movement (which we discuss in more depth later). One was an abrupt and wholesale break with the present-past to enable a clearly articulated new future; while the other seeks to enable gentler processes of change towards less certain futures (whilst simultaneously pre-empting and attempting to avert major shocks).

Geographers have explored the nature, effects and experiences of this transformation, paying particular attention to how it was shaped by specific local social, historical and institutional contexts (Smith and Pickles 1998); and attending to the everyday spaces, practices and diverse economies emerging after economic transformation (Smith and Stenning 2006). Nonetheless, even within Geography, the conceptualisation of such processes as forms of transition persists. For example Reid-Henry (2007: 445) identifies Cuba's recent political and economic changes as aspects of transition. Specifically he argues that:

"The geography of the transition to a postsocialist world encompasses many sorts of change. For countries which formed the 'third world' within what was once the 'second world'- countries such as Cambodia, Cuba and Vietnam for example - transition has not necessarily meant a wholesale rejection of socialism’ (emphasis added), 
The implication is that such wholesale change, encompassing 'privatisation, liberalisation and stabilisation' has indeed been at the core of transition (not transformation) in other post socialist geographical contexts.

Nonetheless, we seek to draw a distinction between concepts of transition and transformation. Specifically, we contend that processes of transition may contain weighty seeds of ambition; but typically do not anticipate a wholesale shift in the future economic mode of production (whether or not such a shift is realised in practice). Remaining at the scale of the nation-state, we thus contrast Post-Socialist societies with Post-Apartheid transition in South Africa. There, during and after transition, (despite the rhetorical commitment to post-capitalist transformation of some key stakeholders) South Africa remained a capitalist society and certain class-based inequalities obtained. But other organisational, political and economic regimes have shifted, most notably, of course, in terms of race relations (Lemon and Clifford 2005).

Marais (2001: 2) has argued that too many analyses of the post-apartheid transition have failed to attend to the structural dynamics that shaped the end of apartheid. Although the anti-apartheid liberation movements had mobilised around an insurrectionary politics of seizing state power, this was not ultimately what happened. The mass democratic movement did not seize power and transform the nation's political economy; their leaders negotiated the (partial) transfer of power. Indeed, as Marais (2001) has argued, the long process of negotiating the post-apartheid transition held together social actors with diverse ambitions for the nation's future, but a shared commitment to resolving the entangled social, political and economic crises it faced. Through this very process of negotiation and holding together, significant on-going social conflict was prevented. For Marais (2001: 2 - 3),

\footnotetext{
"the transition [should] be understood less as a miraculous historical rupture than as the (as yet unresolved) outcome of a convergence of far-reaching attempts to resolve an ensemble of political, ideological and economic
} 
contradictions that had accumulated steadily since the 1970s. [...] At the same time, though, the opposition was unable to force the capitulation of the old order."

The transition held together the elites on all sides of the negotiations (Bond 2000: 5) by 'modernising' South African capitalism from a regime of accumulation based on a racist division of labour and sub-imperial forms of (mostly extractive) 'settler capital' to compliance with global neoliberalism policies. Initially, at least, the promise of basic democratic reforms ensured the compliance of much of the country's Black working class.

Nevertheless, the distinction we strive to articulate here is both a broadly political-economic one, but also a social one, in terms of imagined futures and societal relations to them. We understand 'transformations' as instigating rapid and wholesale change (and disjuncture) in the economic mode of production, in political institutions and ideologies, and in societal norms and aspects of quotidian material life. In contrast, 'transitions' represent significant changes in regimes of accumulation and political institutions that fall short of wholesale transformations in the mode of production (even as tantalising promises of more substantial social change may continue to be drivers of change). They are fundamentally processes of negotiation and compromise in which solutions are sought that can accrue the consent of the greatest number of social actors. The aspirations of diverse sections of society are sewn together in these negotiated transitions - in this way, different anticipated futures are held together in order to preserve (whether deliberately or inadvertently) the functioning of capitalism. Transitions and transformations also differ, we argue, in the specific ways in which they relate to the future. Transformations are enacted towards a (singular) clearly defined vision of the future that is very different to the present. Transformative processes of change anticipate this radically different future (a break from the past), and those who are mobilised to progress it often take solace in the teleological expectation that it will be realised (usually after some kind of tipping point has been reached) Within diverse forms of transitions, literature on socio-technical transitions also suggest teleological, goal oriented processes of change (Shove and Walker, 2010), 
while more nuanced accounts highlight multiple stages and contested, provisional changing goals along transitional pathways (e.g. towards an ultimate goal of a low carbon economy) (Bailey and Wilson, 2009). In the latter formulations in particular, speculation and pre-empting (in ways akin to adaptive management) emerge as key aspects of future orientation.

\section{Lifecourse transitions}

Recent research on the social construction and embodiment of ageing has indicated that lifecourse transitions are - unsurprisingly - not merely events that happen to human bodies with the passing of a significant birthday (Valentine, 2003). Rather, neoliberal policy discourses have frequently tethered lifecourse changes experienced by both young and elderly people to the ability of individuals to make the 'right' transitions that will, in turn, ensure their inclusion in economicallyproductive activity (Ruddick, 2003). In countries like the UK, lifecourse transitions have become subject to forms of affective governmental intervention - whether via the (re)configuration of young people's aspirations for education and employment (Brown, 2011), or through the representation of young people with intellectual disabilities as 'stuck in transition' - neither (economically-dependent) children nor (economically-productive) adults (Butcher and Wilton, 2007).

Meanwhile, the explanatory limits of the notion of youth transition have been highlighted in very recent work. Scholars in youth studies have - although not seeking entirely to escape the concept of transition - highlighted how (seemingly) once-linear forms of progression to adulthood have become more complex and even reversible. Characterising these as 'yo-yo' transitions, Walther (2006) offers a range of explanations: from increased levels of participation in Higher Education to greater uncertainties around employment and career trajectories for young adults. A powerful recent critique by Wyn et al. (2011) seeks to decentre the explanatory power of 'youth transitions' in recent work on young adulthood, arguing for heightened sensibility to the social contexts of young adults' lives (especially the family). 
Perhaps in a more fundamental sense, recent work by children's geographers has sought to undo teleological notions of 'growing up', arguing that a person's progression through the lifecourse is not guided simply by the aim of 'becoming-adult' (Worth, 2009). Rather, it is argued that lives 'go on': that life itself is beset with multiple temporalities, exhibiting different logics and forms of intention (perhaps day-to-day survival), over different timescales (short- and long-term), attended by various emotional dispositions (despair, anxiety, hope) (e.g. Horton and Kraftl, 2006; Kraftl, 2009; Evans, 2010). In this way, multiple futures are opened up and inhabited in ways that the concept of lifecourse transition alone cannot admit - but that, crucially, intersect with other spaces and scales that have been named as 'transition' (such as in efforts to foster community resilience/survival in preparing for the uncertain effects of environmental change).

The lifecourse is but one arena in which modes of individual and collective transition are being increasingly subject to scrutiny - and thereby rendered governable typically in the service of neoliberal futures. The language of transition is so contested because it implies progress or improvement - but through practices and social-technical constellations that seek to reinforce (at most reconfigure) rather than fundamentally alter the status quo. Hence, neoliberal governments have been able to justify large-scale capital investment schemes (for instance in new school buildings) as 'radical' when in fact they are merely allegorical of wholesale social transformation (Jameson, 2005; Kraftl, 2011).

Importantly, we do not suggest that transformation and transition, as distinguished above, are mutually exclusive, as ethnographic work detailing everyday lives during post-socialist transitions has shown (e.g. Burawoy and Verderey, 1999; and Stenning, 2008 for instance, in her work on young people growing up in the former Eastern Germany, Kathrin Hörschelmann shows how individual, lifecourse transitions are experienced in and through Post-Socialist transformation (Hörschelmann and Schaefer, 2007). Such studies highlight not only the co-implication and co-occurrence of transition and transformation, but the multiple, concurrent spatial scales through which transitions are experienced and produced. In the rest of this paper, through two examples, we attempt to 
extend and supplement work on State-level and lifecourse transitions. Significantly, we combine these overlapping but distinct notions of transition with other concepts, borrowing for example from work on 'commons' and Science and Technology Studies.

\section{Holding the Future Together: two approaches to transition from Britain}

In the rest of this paper, we explore two examples of transition discourses in Britain: first, more briefly, we examine the deployment of the term in recent UK Government policy-making; second, we look in more depth at the rapidly-developing Transition movement (and associated Transition Towns). In so doing, we want to make two arguments. First, that the idea of transition is deeply imbricated in future-thinking. Our examples constitute different forms of future-thinking, and imagine very different spaces and practices in and of their respective futures, and ways of relating to those futures. We'll try to sketch out some of these forms, spaces and practices in the three examples that follow. Thus, second, we introduce the idea that each of these examples, in their own diverse ways, attempts to 'hold the future together'. We outline what we mean by this in the course of exploring each example, before identifying some key commonalities and divergences in conclusion.

\section{Transition in UK Government Policy}

In the year before the May 2010 change of Government, the term 'transition' was increasingly being deployed in UK Government policy-making - most noticeably in the UK Low Carbon Transition Plan (2009). In this document, 'transition' (to a low carbon economy) was described as the defining feature of the $21^{\text {st }}$ century (HM Government 2009: 5). The plan used the term 'transition' to signify the scale of the changes that were perceived to be necessary to respond to climate change, peak oil/energy security, and global recession whilst "protecting the most vulnerable" (HM Government 2009: 2). Most significantly, the term 'transition' was explicitly used to hold together different plans 
and strategies covering everything from energy, transport, employment, skills and training through to housing (Foxon et al. 2009).

The Plan recognised that the challenges facing the UK needed the active participation not just of Government, but also business sectors and local communities to tackle them.

"Making the transition will take strategic action by government and a comprehensive plan. This is that plan. It shows sector-by-sector what savings can be achieved and how every department across government will take responsibility. But the changes cannot be done by government alone. ... So alongside the country's low carbon transition plan, every business, every community will need to be involved. Together we can create a more secure, more prosperous low carbon Britain and a world which is sustainable for future generations." (HM Government 2009: 6; our emphases)

Although the Plan contained detailed strategies on various fronts, and (inevitably) set many targets, in sharp distinction from the Transition Towns movement, it was the relative ambiguity and openness about what transitions will lead to that actually allowed for the holding together of diverse constituencies and the enrolling of their collective creativity in finding solutions and commitments that will drive the transition (Nye et al., 2010). The Government's adoption of the term 'transition' seems influenced by its earlier adoption by various influential (and favoured) think tanks and armslength advisory bodies within the wider policy community (IPPR, New Economics Foundation and the Sustainable Development Commission). The New Economics Foundation (nef), in particular, was particularly influential in promoting the notion of a coming 'transition'.

"By sharing our resources more equally, by building better communities and a better society and by safeguarding the natural environment, we can focus on the things that really matter and achieve genuine and lasting progress with 
higher levels of well being. Taken together this would amount to what we have termed the Great Transition." (nef 2010: 4; our emphasis)

In turn, nef had themselves drawn on the ideas and experiences of the grassroots Transition (Towns) movement in advocating a series of proposals for responding to the triple challenge of climate change, peak oil and financial crisis - yet with a much broader-reaching sense of ambition and a far more combinative vision of who and what could be included in a 'Transition' society. In doing so, to varying degrees, they argued for significant shifts in social, economic and political relations as a response to the triple crisis. For example, Tim Jackson's Prosperity without growth? report argued:
"A transition from narrow self-interest to social behaviours, or from relentless novelty to a considered conservation of things that matter, can only proceed through changes in underlying structure. Changes that strengthen commitment and encourage social behaviour. And these changes require governments to act" (p 98)

Although these various bodies are committed to the preservation of capitalist relations, they recognized the need for a significant transition to a different kind of accumulation strategy capitalism on new terms. Talk of 'transition' in this context signified more than just a change of policy: it represented a recognition of the need to enact a more substantial change in the functioning of contemporary capitalism and an openness to finding solutions that would shape that shift.

Despite enacting severe austerity measures, in their first 18 months in power the ConservativeLiberal Democrat Coalition government has retained the emphasis on openness adopted by the previous government in their early rhetoric on the environmental risks facing the UK. Indeed, in the context of growing government rhetoric around notions of crisis (financial, environmental, individual) and the associated urgency of immediate action, the possible futures imagined in 
response have become increasingly diverse, ill-defined and decontextualised. For example, the Coalition government's recent reported 'recalibration' of domestic energy and climate change policy deploys six scenarios to envison pathways to a low carbon future (Department of Energy and Climate Change, 2010). As noted in other critiques of scenario-envisioned futures (e.g. see Garb et al., 2008), the realities of social impacts, consequences and processes of change are readily subsumed in analyses of drivers and trends (HM Government 2010). There is little attention to, or room for discussion as to, the fear and chaos which these changes might enact. It remains unclear how different groups, communities and sectors of the economy will hold together the future under these scenarios.

\section{The Transition Towns movement}

A second key way in which concept of transition is gaining prominence in Britain is through the contemporary Transition movement, perhaps notable for inspiring an ever-growing series of Transition Towns. Transition Towns originated in the Republic of Ireland, but the idea was soon exported to the UK. The first Transition Town in the UK was Totnes (Devon) and was initiated in 2006. Since then, the idea has spread such that in 2010 there were over 400 Transition Towns around the world, a significant proportion in the UK (Smith, 2011).

The transition movement (or 'transition culture' as it is often called) that undergirds Transition Towns has three features. First, the movement is a responsive one, evolving to cope with a series of future perceived threats. As Rob Hopkins (the founder of the first Transition Town) suggests, Transition Towns are "community-led responses to peak oil and climate change, building resilience and happiness" (Hopkins 2008: 8). Second, the transition movement - like many environmental movements before it - privileges collective solutions operationalised at a 'local' scale (Dobson 2000; North 2010). Transition Towns are the manifestation of this philosophy. Generally, each Transition Town represents a pre-existing settlement - a market town, neighbourhood or, in some cases (like 
Transition Nottingham and Transition Leicester) considerable swathes of larger cities. In each case, a group of local residents forms an 'initiating group' who begin to implement a generic Transition Model (explained below). Ideally, that group then encourages the local community at large however defined - to adopt the principles of the Transition Model to better prepare that community (and its locality) for peak oil and climate change. Third, it follows that the precise nature and scope of each Transition Town will vary. However, many Transition Towns draw on a common suite of activities, such as community gardening and food production, re-skilling local people (reviving lost 'know-how' in traditional skills), developing local water and energy supplies, and the introduction of local currencies. Furthermore, formal recognition as a 'transition town' by the Transition Town movement necessitates adoption of a common 12 step programme, culminating in the production of an energy descent action plan (EDAP), a requirement which imposes some degree of commonality, whilst simultaneously attracting criticism for its somewhat prescriptive nature (e.g. see Connors and McDonald, 2010). In a sense, Transition Towns attempt to tie together many of the kinds of 'alternative' economic and social practices that will resonate with readers familiar with intentional and/or eco-communities - yet seek to locate those practices within (rather than outside) the everyday lives of those living in 'ordinary', mainstream towns and cities in the UK. The intention is that these activities are introduced within a community by the initiating group, but that - persuaded both by the imminence, seriousness and inevitability of the threat, and the gains to be made from collective action (greater 'resilience' and 'happiness', according to Hopkins' quotation above) - they will soon be adopted by the majority of residents in that named community (Smith, 2011). The discursive representation of energy descent as not only an inevitable but also as a positive experience is integral to realisation of the Transition movement's agenda (Bailey et al., 2009; ScottCato and Hillier, 2010). As Ahmed (2010) has recently observed, the promise of future happiness serves to orientate lives along particular paths towards end points that are considered to be social goods. The Transition Town movement poses the possibility of future happy low carbon living as an enticement to those considering orientating their lives towards that future in the present. 
A critical feature of the transition movement has been its distancing from radical, politicised debates about climate change and its causes and, in some senses, its partial alignment with UK Government policies such as those discussed above. Notably, Transition Towns have been the subject of increasing debate by geographers (and others) because of their assertion of noncombative, local and 'positive' solutions (North, 2010). For critics (like TRAPESE, 2008), transition culture stands in stark distinction from the need for more resistant, larger scale and critical practices that at least take a clear stance on the causes - not just possible coping mechanisms - for climate change and related social and economic iniquities. Connors and McDonald (2010: 4) contend that, although the Transition Towns movement

\footnotetext{
"incorporates aspects of both community development and social movements . . it differs from both in the expressed apolitical nature of the movement... perhaps unwittingly (it) may be corralling a mass of individual, incidental moments behind the banner of a movement that, because of its inbuilt contradictions and hopeful naivete of politics and power, is bound to disappoint its adherents"
}

In trying to appeal to diverse groups of constituents in diverse kinds of community (of different geographical scales), it has been suggested that the movement's efficacy is so diluted that it simply offers a series of possible practical solutions and little more (TRAPESE, 2008). However, although the politics of transition is explicitly not about taking power but rather constitutes 'progressive politics of declining societal complexity and energy use ... a politics of managing transition during societal decline [and] developing new ways of living' (North 2011), we are nonetheless cognisant that these changes cannot take place without major shifts occurring at the very least in national political and economic structures and resource provision (Monbiot 2007; Hopkins 2008). As Bailey et al. (2010: 598) observe, while the 'Transition movement is not ideologically anti-growth; it simply sees that inevitable oil scarcity makes economic growth irrelevant' (emphasis added). Thus, any attempt to 
label the movement as post-political remains problematic, especially in the context of its focus on localisation, recently highlighted as both deeply political and inherently subversive (North, 2010: 591).

We do not seek to repeat the detailed and critical analyses of the above work; rather, here, we focus specifically upon four key principles around which centre the formulation of Transition Towns (Hopkins 2008). For, taken together, we posit that these principles enact the spacing and timing of the future (or futures) imagined by Transition Towns. The four principles are as follows:

"1) Life with dramatically lower energy consumption is inevitable, and that it's better to plan for it than be taken by surprise;

"2) That our [...] communities presently lack the resilience to enable them to weather the sever energy shocks that will accompany peak oil;

"3) That we have to act collectively, and [...] now;

“4) That by unleashing the collective genius of those around us to creatively and proactively design our energy descent, we can build ways of living that are more connected, more enriching and that recognise the biological limits of our planet" (Hopkins, 2008: 134, from The Transitions Handbook; our emphases.)

In seeking to sell this latter message, the Transition Towns Handbook uses techniques of ' backcasting' to make tangible desirable futures and imaginaries of localised, sustainable and convivial communities in the UK of 2030 (Bailey et al. 2009). If the future imagined by Transition Towns is resolutely not a post-capitalist one - and also not one representative of radical structural critique then the question remains as to how the future is figured and governed by the transition movement through these techniques of 'back-casting'. We argue that the movement attempts to hold the future together in (at least) three ways.

Firstly, the future in which successful local Transition Towns are positioned is an inevitable and geographically undifferentiated one. The Transition Town approach holds that peak oil and climate 
change are a certainty and will affect the entire globe. It therefore follows that a measure of closure - of certainty about the inevitability of these risks, as well as coping strategies (albeit local and not set out by transition culture) is desirable. Thus, whilst arguably remaining open to 'where local Transition Towns want to go', the spatial and performative manifestations of the movement are held together and provided a sense of imaginative closure by these principles of inevitability, universal applicability, associated dampening of shock and 'surprise' and urgency of action (Anderson 2010). Discursively, Transition Towns - and their futures - are all governed by the same premise: the certainties of global energy scarcity and climate change. Notably, this strand of Transition thinking stands in stark contrast to feminist and poststructural visions of the future that emphasise (almost) total fluidity and open-endedness (Sargisson, 2000).

Secondly, communities need to be better at 'holding themselves together', in the future. They lack resilience - a key word for the movement. Here, resilience may be figured in part as simply remaining static (or moving forward or differently to remain happy and content). As Law and Mol (2001) demonstrate in their explication of technoscience spatialities, in network terms, resilience denotes the amount of change a system can undergo and still retain the same function, structure and, crucially, relationships between its component parts. If it remains resilient, in the aftermath of a change or shock, it survives as the named entity - ship, water pump, perhaps even a town - that it was before. It remains identifiable from past through present to future. Thus the question is - what local practices and spaces are necessary to ensure the continued viability of the 'local communities' as designated (and even created) by named Transition Towns (Leicester, Nottingham, Brighton)? How far must the relationships and activities that constitute those communities (and places) change such that they remain in-place, unthreatened and, ideally, preserve as much of the contemporary everyday lives of those places and their inhabitants?

Thirdly, Transition Towns privilege acting collectively and locally, for the future. Transition Towns call for a (re)imagining of the local that evokes a series of previous 'restorative' and/or ecological utopias that stress change at the local scale (Sargisson 2000). In doing so they at once imbue the 
local with particular attributes, for example as expressed in normative notions of 'convivial communities', through practices of intentional localisation (North 2010), necessitating negotiation of the 'local trap' (Brown and Purcell 2005), and enact a 'subversive project in relation to neoliberal globalisation' (North, 2010: 591). It is only a short step from these latter concerns to emergent debates over the 'new commons', wherein concerns with communal ownership of land and resources, at the heart of traditional commons debates, are expanded to encompass more widely transformative agendas. Specifically, 'new commons' suggests new physical spaces of communal ownership and engagement (ranging from community orchards and greenspaces to revitalised Scottish crofting commons), but also critically, shared heritage and shared rights therein, including social and cultural resources (compare Pinkerton and Hopkins 2009). As argued below:

"The commons is what we share together. From parks and clean water to scientific knowledge and the Internet, some things are no one's private property. They exist for everyone's benefit, and must be protected for future generations. A movement is emerging today to create a commons-based society." (On the Commons, 2010)

Thus the 'new commons' invokes a project of resistance to privatisation and globalisation, wherein the commons may be understood as a movement, or a worldview, grounded in, but moving beyond idealised visions of a pre-enclosure countryside in the UK, to new, localised societal practices and organisation, which share much with the Transition Towns movement and the possible futures it suggests.

Tellingly, the futures of Transition Towns are then, partly, located in the priorities of the past although, crucially, they lack any firm utopian vision, favouring piecemeal process and the restoration of traditional skills (for instance building, maintenance and craft skills) and communal rights. However, the most notable feature of the third principle articulated by Hopkins (2008) is the imperative to act 'now'. Transition culture is, if nothing else, imbued with a local sense of urgency- 
of acting here and now - that the above-mentioned threats press upon local communities. Thus, taking the principles of resilience and urgency together, the transition movement narrates attempts to hold together, in a conceptual sense - the progress of time by stitching together past (restoration) with present (urgency) and future (resilience). These are not three distinct timespaces; rather, they form a conceptualisation of history which situates local communities as groups of actors in a 'specious present' (Dodgshon 2008) where past habit and memory, present and future hope are tethered to the present. In Transition Towns literature, this specious present situates local communities on a receding horizon; as always-already on the cusp between resilience and breakdown - a cusp that is becoming ever-sharper, ever-more-quickly (Mason and Whitehead forthcoming $a$ ). The future is pressing upon the present, compelling communities - here and now to take action in order to hold firm; to become resilient or suffer the consequences. Transition culture presents a compelling form of affective governance (Smith 2011) that has the power to bring people into line; if, in the face of potentially disastrous climate change, our options are limited, then surely it is only logical to join a gathering movement and accept its premises, rather than go it alone?

Finally, there is a sense in which local experiments in 'transition' are being increasingly articulated as 'niches' in networks with new spatio-temporal logics. In these logics, niches of creativity and alterity are reconfigured as points of articulation, departure and collection for discourses that may 'trickle' or permeate more broadly over time and space, even if in a slightly diluted or mutated form. Inspired by Science and Technology Studies, this is the argument of Dutch theorists of transition. What the Dutch transitions management school might conceive as experimental niches (Geels 2005; Seyfang 2009), John Holloway (2010) might also identify as the cracks from within which postcapitalist relations based on concrete doing rather than abstract labour might emerge. For Holloway, the imperative is neither to develop experimental niches from which capitalism might develop in more sustainable ways, nor to overthrow and destroy capitalism; rather, he advocates connecting and expanding those ruptures in the logic of capitalism, thereby refusing to continue (re)creating it and doing something different instead. Thus, in this more radical reading of its 
potential, the 're-commoning' of local community assets through Transition Town initiatives might help rupture our alienated obsession with the consumption of commodities and be part of a 'crack' in the system of capitalism. Cracks break down existing relations to open up possibilities for diverse futures that are not held together by the premises and promises of neoliberal capitalism.

Thus there is a tension over place in the Transition Towns model. On the one hand places may be theorised as loci at which the detailed business of transition is given flesh through the performance of resilience in coping with an unpredictable future. Holding together occurs in and for local places and communities, if they can become more resilient. On the other, following Massey (2005), Transition Towns are places beyond place, figured as niches from which larger-scale alternative futures might flow. In this sense, multiple local examples are held together (and held up) as examples from which larger scale forms of resilience might be supported - but which might, recursively, also open up 'cracks' in the veneer of neoliberal capitalism.

Ultimately, and perhaps quite simply, Transition Towns attempt to 'hold the future together' because they are trying to tread a path between, and resolve, a series of complex, sometimes opposing imperatives that operate within and at the margins of contemporary neoliberal democracies. They offer something akin to an 'interim vision' (Connolly 2008) that is neither a fullblown utopian vision of shattering social transformation (Mannheim 1960); nor an affirmation of ignorant 'business-as-usual', even if some commentators argue that they will do little to challenge the deep-seated problems inherent to neoliberal capitalism. They play with and weave together senses of open-ness and closure which hold together a future of particular global certainties (climate change) and local uncertainties (its local effects). Finally, they attempt to hold communities together - practically and, perhaps more controversially, ideologically - through an affective rendering of the future as one (increasingly) pressing upon the cosy expectations and everyday lives of local communities (Kraftl 2007). Thus, Transition Towns effect a mode of governance that seeks less explicitly to govern the future, and rather more implicitly to govern via the future and the possibility of democratising action upon the future by holding together, here and now. 


\section{Conclusions}

Our argument in this paper has been that - across varied political and social terrains - the notion of transition has gained increasing currency over the past decade, especially in Britain. Transition is a powerful concept, especially when deployed as a governmental tool, because philosophies, politics and practices of transition tie together categories often held in tension: individual/collective; open/closed; active/passive - and so on. Notwithstanding difficulties over the definition of transition (in particular qua transformation), the term has also gained increasing prominence in the social sciences as a way of analysing change. Yet, as we suggested at the beginning of this paper, there have remained at least two problems with social-scientific analyses of transition. First, it has been difficult to disentangle what marks out 'transition' from other philosophies, politics and practices of and for change. Second, there has been little critical analysis of the temporalities involved in making, imagining (or being subject to) transition. This paper has begun to address these lacunae by teasing out some of the many styles of future-thinking associated with transitions. We argue in closing that it is vitally important to theorise the times and spaces of the future imagined by transition, as they hold the future together, rendering it governable, via several key principles.

First, transition philosophies, policies and practices use the principle of combination in order to render future (local and/or national) populations governable. They seek to hold together diverse groups, ideologies and visions of the future, channelling them towards increased skills competencies (as in Transition Towns) or certain kinds of responsibility and 'social behaviours' (as in policy rhetoric from the political Left and Right in the UK). As they have become increasingly widespread, in Britain and beyond, transition approaches have become subject to mounting scrutiny - especially over their inclusion of diverse social and cultural populations, and over their unwillingness to engage in structural critiques about the causes of Peak Oil and climate change. Yet critiques of movements like Transition Towns fail to acknowledge the significant and critical suite of ways in which transition 
relates to the future. We have outlined a number of ways in which the Transition Towns movement attempts to 'hold the future' together, not least by imagining communities that are more resilient and better able to cohere in the face of imminent threats. Whilst not always positing entirely novel or acceptable modes of pre-emption and precaution (Anderson 2010), Transition Towns are particularly noteworthy because they mark out the future as one of open-ness and closure, of radical possibility and - to some degree - business as usual. Crucially, through concepts like resilience, these examples aim to hold together pre-existing socio-spatial orderings - local neighbourhoods, towns, contemporary standards of living, neoliberal capitalism - with new, creative and unanticipated practices, skills and emotions that might contain within them the beginnings of 'cracks' in those pre-existing orderings.

Second, transition approaches rely on the principle of compulsion in order to hold subjects together. The vast majority of approaches to transition are characterised by a sense that the (riskladen) future is pressing upon the present, perhaps more than ever before. There is also striking agreement about that future across the examples we have discussed here, such that the risk-laden future is virtually a singular, universal, closed one (of Peak Oil and climate change), albeit whose local consequences are hard to predict. Transition practices and experiments are driven forward by imminent threats that barely require repeating; indeed, that is the point - they require simple and repetitive iteration until they become ingrained within the very mindset of individuals and communities. In the case of Transition Towns, as Smith (2011) has highlighted, the rhetoric is of weaning individuals and communities off an addiction to oil because of the inevitable, disastrous consequences of that addiction. The principle of compulsion is, then, a mode of affective governance that uses barely spoken, inevitable future threats in order to re-wire the psyche of individuals and communities towards more resilient ways of living. Hence, the subjects of transition are held together and held in line through transition approaches that always compel them to act in the face of the near-future. 
Third, transition approaches rely on but struggle with the principle of emplacement. The spaces, places and demarcated scales of transition - notably, in our examples, the local and the national are critical to but deployed in different ways to enable the future to hold together. We have demonstrated the repeated and continued emphasis upon local places, communities and forms of material action - from alternative economic practices to eco-building technologies - by advocates of transition. Whilst relying on the principle of compulsion - and its universal rendering of the future transition approaches tend to insist upon the production and performance of local, contingent, sensitive and creative responses in the face of those global threats. Transition does not work without (local) places because those places offer the milieu - and the affective attachments - through which generic senses of responsibility, resilience and relatedness may be most easily imagined and held together.

Transition, then, requires the earthy materialities of place as much as and in order to (con)figure the vagaries of the future. And yet, this is where an implicit counter-argument surfaces in this paper: that transition policies, philosophies and practices also break apart, disentangle and decoct the spaces of the future. Three examples from our preceding text illustrate this. First, the insistence in Transition Towns discourse upon localism borders (sometimes explicitly) upon modularity. That is, the drawing of borders around places as part of an insistence that local places can be more resilient if they are less connected to other places and, essentially, exchange fewer responsibilities with one another. In the context of geographical theorising about responsibility at a distance, and the incessant connectivity of places (Massey 2005), this is a key problem for such approaches to transition. Second, Transition Towns are predicated on a (slightly counterposed) model of 'niches' where successful individual examples will spread, almost virally, across time and space. The question is whether those places (as they are encouraged towards self-sufficiency) will actually cohere to constitute a larger network or social movement, or if they will remain disparate places connected only by the willingness to transition. On the other hand, as we have suggested, these niches might be figured as the 'cracks' through which a more radical challenge to neoliberal capitalism might 
emerge - a possible rupturing of the future rather than a holding-together. Finally, the direction of policy rhetoric in the UK since May 2010 has been one in which the national population is very much 'in this together, apart'. In the transition through austerity, the entire population has been compelled to be patient whilst public expenditure has been massively reduced. In this context, everybody must 'do their bit', fulfilling the somehow biologically-ingrained imperative to care, to help, to support others. Yet that imperative (if it exists at all) may be expressed in highly uneven ways, probably locally, and quite possibly along familial, religious, economic or other fault-lines. Transition has, in this reckoning at least, become profoundly and problematically dis-placed such that the generic 'togetherness' posited by the current UK government is as likely to disrupt as it is hold together social spaces in the future.

This paper should not be read as a call to re-locate transitions at the local scale. Nor would we advocate a 're-materialisation' of transition practices that privileges a sweeping critique of modes of future-thinking that are open-ended and apparently untethered to the materialities, flows and territories of particular places. Each of these arguments has its merits and pitfalls. Rather, our final contention is that a careful, ongoing reading of the deployment of spatial discourses and practices is as vital to understanding transition approaches as is ongoing attention to the futures in which those transitions are imbricated and, frequently, held together. 


\section{Bibliography}

Ahmed, S. (2010), The Promise of Happiness, Durham, NC: Duke University Press.

Anderson, B. (2010) Precaution, pre-emption, preparedness: anticipatory action and future geographies. Progress in Human Geography 34, 777-798.

Bailey, I., Hopkins, R and Wilson, G. (2009). Some things old, some things new: the spatial representations and politics of change of the peak oil relocalisation movement. Geoforum 41 (4): 595-605.

Bailey, I. And Wilson, G. (2009). Theorising transitional pathways in response to climate change: technocentrism, ecocentrism, and the carbon economy. Environment and Planning A, 23242341.

Bond, P. (2000), Elite Transition: From apartheid to neoliberalism in South Africa, London: Pluto Books.

Brown, G. (2011) 'Emotional geographies of young people's aspirations for adult life', Children's Geography 9(1): $7-22$.

Brown, J.C. and Purcell, M. (2005). There's nothing inherent about scale: political ecology, the local trap and the politics of scale in the Brazilian Amazon. Geoforum 36: 607-624.

Burawoy, M. and Verderey, K. (1999) Uncertain Transition: Ethnographies of Change in the PostSocialist World. London: Roman and Littlefield.

Butcher, S. \& Wilton, R. (2007) Stuck in transition? Disabled youth and the challenge of paid employment. Geoforum 39, 1079-1092.

Connolly, W. (2008) Capitalism and Christianity, American Style. Durham, USA: Duke University Press. 
Connors, P. and McDonald, P. (2010) Transitioning communities: community, participation and the Transition Town movement. Community Development Journal . doi: 10.1093/cdj/bsq014. Advance access online http://cdj.oxfordjournals.org/content/early/recent.

Department of Energy and Climate Change (2010). Coalition sets out energy policy as new analysis points to scale of 2050 challenge (Press release). http://www.decc.gov.uk/en/content/cms/news/pn10 85/pn10 85.aspx.

Dobson, A. (2000) Green political thought. London: Routledge.

Dodgshon, R. (2008) In what way is the world really flat? Debates over geographies of the moment Environment and Planning D: Society and Space 26, $300-314$.

Evans B (2010) Anticipating fatness: childhood, affect and the pre-emptive 'war on obesity'. Transactions of the Institute of British Geographers 35:21-38.

Fosket, J and Mamo, L (2009) Living Green: Communities that sustain. New Society Publishers, Gabriola Island, Canada.

Foxon, T., Reed, M and Stringer, L. (2009a) 'Governing long term social-ecological change: what can the adaptive management and transition management approaches learn from each other?' Environmental Policy and Governance 19, 3-20.

Foxon, T J, Hammond, G P, Pearson, P J, Burgess, J and Hargreaves, T (2009b), 'Transition pathways for a UK low carbon energy system: exploring different governance patterns', paper for 1st European Conference on Sustainability Transitions: "Dynamics and Governance of Transitions to Sustainability", Amsterdam, The Netherlands, 4-5 June 2009

Garb., Y., Pulver, S. and VanDeveer, S. (2008). Scenarios in society, society in scenarios: toward a social scientific analysis of storyline-driven environmental modelling. Environmental Research Letters 3: 1-8.

Gardiner, M. (2004) Everyday utopianism: Lefebvre and his critics. Cultural Studies 18: 228-254. 
Geels, F, W (2005) Technological Transitions and Systems Innovations: A Co-evolutionary and SocioTechnical Analysis. Edward Elgar, Cheltenham.

Hendriks, C.(2009) Policy design without democracy? Making democratic sense of transition management. Policy Science 42, 341-368.

HM Government (2009), The UK Low Carbon Transition Plan: national strategy for climate and energy, Norwich: TSO.

HM Government (2010), 2050 pathways analysis report. Norwich: TSO. Available online at http://www.decc.gov.uk/en/content/cms/what we do/lc uk/2050/2050.aspx.

Hörschelmann, K. \& Schäfer, N. (2007) 'Berlin is not a foreign country, stupid!' - Growing up 'global' in Eastern Germany. Environment and Planning A 39: 1855-1872.

Hörschelmann K, and Stenning AC (2009) Ethnographies of postsocialist change. Progress in Human Geography, 32: 339-361.

Holloway, J. (2010), Crack Capitalism, London: Pluto Press.

Holmes, L. (1997), Post-communism: an introduction, Cambridge: Polity Press.

Hopkins, R. (2008), The Transitions Handbook. From oil dependency to local resilence, Totnes: Green Books.

Horton, J. and Kraftl, P. (2006) Not just growing up, but going on: children's geographies as becomings; materials, spacings, bodies, situations. Children's Geographies 4: 259-276.

Jackson, T. (2009), Prosperity without growth: The transition to a sustainable economy, London: Earthscan.

Jameson F (2005) Archaeologies of the Future: The Desire Called Utopia and Other Science Fictions. London: Verso. 
Karl, TL. and Schmitter, PC. (1991), 'Modes of transition in Latin America, Southern and Eastern Europe,' International Social Science Journal, 43: 269 - 284.

Kraftl, P. (2007) Utopia, performativity and the unhomely. Environment and Planning D: Society and Space 25,120-143.

Kraftl, P. (2009) "Utopia, childhood and intention", Journal for Cultural Research, 13(1): 69-88.

Kraftl, P. (2011, in press) Utopian Promise or Burdensome Responsibility? A Critical Analysis of the UK Government's Building Schools for the Future Policy. Antipode.

Law, J. and Mol, A. (2001) Situating technoscience: An inquiry into spatialities. Environment and Planning D: Society and Space 19, 609-621

Lemon, A. and Clifford, D. (2005), 'Post-apartheid transition in a small South African town: interracial property transfer in Margate, Kwazulu-Natal,' Urban Studies, 42 (1): 7 - 30.

Lynn, NJ. (1999), 'Geography and Transition: reconceptualising systemic change in the Former Soviet Union,' Slavic Review, 58 (4): $824-840$.

Mannheim K (1960[1936]) Ideology and Utopia: An Introduction to the Sociology of Knowledge. London: Routledge.

Marais, H. (2001), South Africa: Limits to change - the political economy of transition, London: Zed Books.

Mason, K. \& M. Whitehead (forthcoming a) Between Here and There: Mobilizing Urban Vulnerabilities in Climate Camps and Transition Towns. In Dooling, S \& Simon, G. (Eds) Urban Vulnerabilities: Cities, Nature, Development. Burlington, USA. Ashgate.

Mason, K. \& M. Whitehead (forthcoming b) Transition Urbanism and the Contested Politics of Ethical Place Making. Antipode.

Massey, D. (2005) For space. London: SAGE.

Monbiot, G (2007) Heat: How can we stop the planet burning. Penguin, London 
On the Commons. (2010) The commons movement. http://onthecommons.org/. Downloaded 12.11.2010

New Economics Foundation (2010), The Great Transition, London: New Economics Foundation.

North, P. (2010), 'Eco-localisation as a progressive response to peak oil and climate change - a sympathetic critique,' Geoforum, 41: 585 - 594.

North, P. (2011) "The politics of climate activism in the UK: a social movement analysis", in Environment and Planning A 43: 1581 - 1598.

Nye, M., Whitmarsh, L., Foxon, T. (2010) Sociopsychological perspectives on the active roles of domestic actors in transition to a lower carbon electricity economy Environment and Planning A 42, 697 - 714.

Pickles, J. and Smith, A. (eds) (1998) Theorising Transition: the political economy of post-communist transformation, London: Routledge

Pinkerton, T. and Hopkins, R. (2009), Local Food: How to make it happen in your community, Totnes: Transition Books.

Reid -Henry. S. (2007) The contested spaces of Cuban development: post-socialism, post-colonialism and the geography of transition. Geoforum 38 (3): 445-455.

Ruddick, S. (2003) The politics of aging: globalization and the restructuring of youth and childhood. Antipode 35: 334-362.

Sargisson L (2000) Utopian Bodies and the Politics of Transgression. London: Routledge.

Scott-Cato, M and Hillier, J (2010) How could we study climate-related social innovation? Applying Deleuzean philosophy to Transition Towns. Environmental Politics, 19, 6, 869-887.

Seigworth, G. (2000) Banality for cultural studies. Cultural Studies 14, 227-268 
Seyfang, G. (2009) The New Economics of Sustainable Consumption: Seeds of Change. Palgrave Macmillan

Shove, E. and Walker, G. (2010). Governing transitions in the sustainability of everyday life. Research Policy 39, 471-476.

Smith, A. (2011, in press) Community-led urban transitions and resilience: performing Transition Towns in a city. In Bulkeley, $\mathrm{H}$ et al eds. Cities and Low Carbon Transitions. London: Routledge.

Smith, A. (1996), 'From convergence to fragmentation: uneven regional development, industrial restructuring and the 'transition to capitalism' in Slovakia,' Environment and Planning A, 28 (3): $135-156$.

Smith, A. and Pickles, J. (1998), 'Introduction. Theorising transition and the political economy of transformation,' in Pickles, J. and Smith, A. (eds) Theorising Transition: the political economy of post-communist transformation, London: Routledge. pp. 1-22.

Smith, A. and Stenning, AC. (2006), 'Beyond household economies: articulations and spaces of economic practice in postsocialism,' Progress in Human Geography, 30(2): $190-213$.

Stenning, AC. (1997), 'Economic restructuring and local change in the Russian Federation,' in Bradshaw, M (ed.), Geography and Transition in the Post-Soviet Republics, Chichester: Wiley. [check page \#s]

TRAPESE (2008) The Rocky Road to Real Transition: the transition towns movement and what it means for social change, available online at http://trapese.clearerchannel.org/index.php

Valentine, G. (2003) Boundary crossings: transitions from childhood to adulthood. Children's Geographies 1, 37-52.

Walther, A. (2006) Regimes of youth transitions: Choice, flexibility and security in young people's experiences across different European contexts. Young 14: 119-139. 
Worth, N. (2009) Understanding youth transition as becoming: Identity, time and futurity. Geoforum 40: $1050-1060$.

Wyn, J., Lantz, S. and Harris, A. (2011) Beyond the 'transitions' metaphor: Family relations and young people in late modernity. Journal of Sociology 47: 1-20. 